\title{
Human Rights Concept in Islamic Legal Thought
}

\author{
Dede Husni Mubarok \\ Institut Agama Islam Darussalam (IAID) Ciamis Jawa Barat \\ Email: dedehusni.mubarok@gmail.com
}

Alief Akbar Musaddad

Institut Agama Islam Darussalam (IAID) Ciamis Jawa Barat

\begin{abstract}
ABSTRAK
Ketika rezim orde baru tumbang, tuntutan atau aspirasi formalisasi syari'at Islam di Indonesia gencar disuarakan oleh sekelompok umat Islam, baik melalui proses politik maupun dalam interaksi di ruangan publik. Tetapi kelompok lain baik dari kalangan sekular maupun Islam sendiri merasa khawatir dengan formalisasi syari'at Islam, karena banyak ketentuan dalam syari'at dianggap tidak sejalan dengan pilar-pilar demokrasi dan Hak Assai Manusia seperti kebebasan, kesetaraan gendar, persamaan kewarganegaraan dan tolerasi. Dua kutub yang tampak kontradiktif tersebut menarik untuk dikaji melalui pendekatan etimologis dan terminoligis terhadap term syari' at tersebut dalam interpretasi-kolerasional teks-teks Alqur'an dan sunnah beserta dinamika pemaknaannya secara historis, sehingga akan melahirkan image syari'at Islam yang ramah, penuh kedamaian, dan menghormati hak-hak kemanusiaan. Karena itu, syari'at Islam yang berwatak fleksibel, elastis, tolern dan inklusif ini secara substansial dapat diterapkan di tengah-tengah realitas sosial yang multikultural, multi religious dan multi etnik dalam konteks penegakan demokrasi dan penghormatan hak asasi manusia.
\end{abstract}

\begin{abstract}
When the New Order regime fell, demands or aspirations for the formalization of Islamic law in Indonesia were intensively voiced by a group of Muslims, both through the political process and in interactions in the public sphere. However, other secular and Muslim groups are worried about the formalization of Islamic law because many provisions in sharia are considered inconsistent with the pillars of democracy and human rights, such as freedom, gender equality, equality of citizenship, and tolerance. The two seemingly contradictory poles are interesting to study through etymological and terminological approaches to the terms of the Shari'ah in the correlational interpretations of the Qur'an and Sunnah texts and the dynamics of their historical meanings so that it will give birth to the image
\end{abstract}


of Islamic Shari'ah which is friendly, full of peace, and respect for human rights. Therefore, Islamic law, which is flexible, elastic, tolerant, and inclusive, can substantially be applied in the midst of multicultural, multireligious, and multi-ethnic social realities in the context of upholding democracy and respecting human rights.

Keywords: Universal Declaration of Human Rights, formalization of shari'ah, democratic system, universal values of shari'ah, mashlahah al-nâs

\section{INTRODUCTION}

The political atmosphere in post-New Order Indonesia is clearly marked by the euphoria of democracy and political liberalization. This phase of political liberalization was marked by the abundance of aspirations that were publicly expressed after being stifled by the authoritarianism of the New Order. One form of political liberalization, as predicted by William Lidle in $1996 \mathrm{AD}$, is that in a more open climate, a more formalistic expression of Islam (Islamic scriptualism) will emerge, considering that they have many political resources to disseminate their issues and demands through media organizations, and their access to politicians (Salim and Azra, 2003).

At least, there are four phenomena of the emergence of formalistic Islamic expressions, in the current context. First, the establishment of many Islamic political parties which mostly adopted Islam as the principle to replace Pancasila. During Suharto's authoritarianism, Pancasila had to be used as the basis or principle of every Organization by force. After the fall of the New Order regime and the reformation order, two Islamic parati- ties, the United Development Party (PPP) and the Crescent Star Party (PBB), insisted on amending Article 29 of the 1945 Constitution to include seven words, namely "with the obligation to carry out Shari'ah". Islam for its adherents. The electronic and print media have been aggressively reporting on the debates between Islamic nationalists and Islamic secularists in various MPR annual sessions regarding the formalization of Islamic law by amending Article 29 of the 1945 Constitution. Outside the session, the two largest Islamic organizations, NU and Muhammadiyah, did not approve of the amendment. , because it will damage the nation-state of Indonesia which is plural and plural. With these seven words, Shari'ah will officially have a constitutional status in the Islamic legal system in Indonesia. The proposal to include a clause that obliges Muslims in Indonesia to carry out Islamic law failed in the three annual sessions of the People's Consultative Assembly (MPR), in 2000, 20001 and 2003. However, it is possible that the two parties will continue to convey the same aspirations. the same in future sessions of the MPR, or in the form of other regulations such as Regional Regulations 
(Perda) with Islamic shari'a nuances in various cities and regencies throughout Indonesia.

Second, the growing demands from specific regions in Indonesia to implement the formalization of Shari'ah are increasingly echoing. There are at least 4 provinces and 6 regencies/cities that are recorded as voicing the formalization of Islamic law. Aceh Province is the only area that legally has a definite legal basis regarding the formalization of Islamic law, but there is no apparent tendency for the substance of Islamic teachings to be enforced. Third, the emergence of Muslim groups that are considered radical, such as Laskar Jihad, the Islamic Defenders Front (FPI), Hizbut Tahrir Indonesia (HTI) and the Indonesian Mujahidin Majlis (MMI) which spread throughout the country. They, especially FPI and Laskar Jihad carrying out control in the private sector, tend to be radical and complex without compromising on discotheques, nightclubs and entertainment venues that smell immoral by carrying the jargon, 'amar ma' rûf nahy munkar. It is not surprising, then, that they face other communities, including Muslims who cannot accept religious understanding and radical ways, because it will damage the image of Islam that loves peace.

Lastly, the soaring popularity of Islamic magazines and media. Sabili magazine for example, according to a survey conducted by AC Nielsen, achieved the second largest circulation after the women's magazine, Femina (Mujani, 2003:19). The weekly Sabili magazine, which was founded underground during the New Order, was used as a propaganda medium to promote political Islam from a radical point of view. Some of the opinions developed clearly support the formalization of Islamic law in Indonesia. The argument is because the positive direction in Indonesia is blinded by humans, not made by God (Ilâhi). Sabili believes that the answer to the crisis in Indonesia is to return to God's way by consistently applying Islamic law.

These four recent developments seem to lead to the application of Islamic law at the state level, either through legal coercion or through political support from state apparatus and apparatus. Therefore, some observers assume that the growing aspirations regarding the application of Islamic law represent a return to the idea of an Islamic state. The interaction between Islam and politics has been an integral part of the Indonesian experience since the days of the Islamic empire in the seventeenth century. It is inevitable that their nexus is associated with the idea of an Islamic state (Syazali, 1990). Most of the characteristics of the idea of an Islamic state that are most visible on the surface are the formal application of Islamic law, in which the relationship between Islam and politics is highly dependent on the extent to which Islamic law is implemented by the state.

The emergence of the above trends is an interesting phenomenon to observe, not only in terms of technical application, but also in revealing the 
missing dimensions of the discourse of Islamic law. At least there is a wide space to re-understand Islamic Shari'a which has been synonymous with the term "implementation and legislation" (tartîb wa taqnîn). The discourse of Islamic shari'ah is complicated with regard to the nature of the relationship of Islam as a form of belief or religion with the historical formulation of Islamic law which has been called shari'ah. When Shari'ah is discussed in a historical and profane locus and context, Islamic Shari'ah must be placed in a fair assessment frame without expecting any privileges because of the assumption of the sacredness of its function and source. According to An$\mathrm{Na}^{\prime} \mathrm{im}$, shari'ah is not the whole of Islam itself but is merely an interpretation of the basic text (nash) is understood in a certain historical context. Therefore, the Shari'ah that has been compiled by the pioneers can be reconstructed in certain aspects, as long as the reconstruction is also based on the same basic Islamic sources and is fully in accordance with the substance of the moral and religious message (An-Na'im, 1990). :57).

The discourse around Islamic law is not an easy matter, for several reasons. First, the debate on Islamic law is not a new discourse, but is a historical burden that has not yet been completed. Second, there is an artificial and reductionist understanding, when Islamic Shari'ah is narrowed down to the scope of rigid and rigid legal provisions so that a sinister face appears that displays a lousy cover of Islamic Shari'ah. And third, the tendency to understand Islamic Shari'ah as a totalistic solution (al-haq almuthlaq), resulting in the shallowing of the universal values of Islamic Shari'ah which actually serves a menu of wisdom, wisdom, peace and enlightenment of civility and a view of life dynamic one.

The three things mentioned above can be used as a starting point for uncovering the curtain of Islamic law which is still "mysterious" and does not have a precise performance. In addition, there are clearly contradictions between the ideal values of religion that teach balance, justice, tolerance, truth and humanity with the application of Islamic law at the practical level which necessitates hostility and severance of relations with non-Muslims, violence and the implementation of hegemonic laws and even not humanist. Therefore, secular and non-Muslim groups do not want the formalization of Islamic law, either in part or in whole. Even some Islamic groups themselves do not agree, because many provisions in the Shari'ah are seen as inconsistent with democracy and human rights, such as freedom of religion which is the most fundamental freedom, because classical figh imposes the death penalty on people who leave Islam (apostates). In addition, there is also a problem, when the opinions and desires of the majority are contrary to the Shari'ah, which one should take precedence? Then in a democratic system there is the principle of equality between citizens, while in classical figh there is inequality between Muslims and non-Muslims (kâfir Dzimmi). In classical literature, such as Fath al-Mu'în, Kifâyah al-Akhyâr, and al-Yâqût al-Nafîs fi Madzhab Ibn Idrîs al-Syafi' $i$, always include apostate sub-chapters 
with the editor, fashl fî riddah, bab al- riddah wa mâ yuf'al bi al-murtad. The loading of the term apostasy is based on the hadith text which states that people who leave Islam must be killed (man baddala dinah faqtulûh). Likewise, the position of women, the Qur' an clearly mentions three things that show the inequality between men and women, polygamy, inheritance, and testimony. These three issues are seen as discriminatory against women, and contrary to gender equality as regulated in article two of the United Nations (UN) Universal Declaration of Human Rights.

Human rights have become a public discussion since World War II, especially after the United Nations (UN) succeeded in proclaiming the Universal Declaration of Human Rights on December 10, 1948 AD, which contained the principles of freedom, equality, ownership of property, rights in marriage, education, work rights, and freedom of religion, including changing beliefs. The root of the basic thought of human rights, initially related to the doctrine of natural law that humans naturally bear a series of natural rights that are eternal and cannot be revoked, abandoned, and reduced because of the demands of the king's divine rights (Nadj \& Mardiniah, 2000:1). At the beginning of its development, the doctrine of natural law taught more on the side of obligation and overrides the central idea of human rights which emphasizes equality and independence. It was only in the 17th century, the foundation of equality and freedom was laid as the foundation of human rights.

In the jurisprudence discourse, there are two concepts of rights, namely human rights and God's rights (haqq al-insân wa haq Allah) where each of these rights underlies each other. This division of rights becomes the basis for the normative provisions contained in Islamic law, so that matters concerning Adam's rights, the business must be with humans themselves, only then with Allah (Zahrah, t.th.: 323-324). The Qur'an itself has stated globally about various lives and their solutions, even the Prophet's hadith clarifies the Word of God, so that humans improve the quality of their piety and solve multiple life problems. In this regard, Islamic countries which are members of the Organization of the Islamic Conference on August 5, 1990 AD in Cairo, issued a Declaration on Human Rights in accordance with Islamic Shari'ah as the only source of reference. Based on the Qur'an and Sunnah. The concept of human rights formulated by the Organization of the Islamic Conference (OIC) countries is called the Cairo Declaration, which has several similarities and similarities in its application and reality, especially on general issues with the Universal Declaration of Human Rights. Human Rights (The Universal Declaration of Human Rights) which was born by the United Nations in 1948 (Lopa, 1986:211).

In the theme of this paper, I want to open the widest public discourse about Islamic law, including public access to reformulate the theme of 
Islamic law in accordance with the interests and benefits of mankind in general, and the plural and multicultural Indonesian society in particular, so that the terms of Islamic law which have been closed by institutional authorities such as the MUI and political parties supporting the Jakarta Charter can be reopened to the public space for intense discussion in order to get to know more proportionally the diversity of opinions and interpretations in their application and actualization. In this short article, we attempt to examine Islamic shari'a, its elasticity and relativity, the diversity of interpretations, schools of thought to the diversity of its application and actualization in public life which are relevant to issues of Human Rights which are the jargon of Western democracies.

\section{METHOD}

This study uses a literature review method or literature review. In this study, a literature review is used to explore scientific sources on the concept of human rights in Islamic legal thought to provide an overview of the development of Islamic thought in the field of human rights.

\section{RESULTS AND DISCUSSION}

\section{Shari'ah Discourse in Comparative Study}

Shari' ah as a term in the treasury of Islam is one of several issues that dominate the discourse of the Muslims. Around these words there are views and understandings that are very deep and widespread, which makes Islam, even all religions, impossible without that view and understanding. Deep and broad notions that are usually abstract are always prone to distortion and blurring, either because of the process of narrowing or disproportionately expanding. Like the flow of a river, its upstream is naturally purer and clearer than its downstream. The input of external elements into the flow of river water does not always mean pollution, there are even mixed elements that make the original material stronger and more valuable.

Thus, knowing enough about the authenticity of an understanding will certainly be more useful. By exploring the original state, it will be easy to know the elements of pollution that have occurred. Shari'ah which is so important in Islam, especially when discussing the concept, it is very necessary to obtain a more original understanding, in order to direct the discussion to forms that are more valid, productive and useful. One of the distortions about the notion of shari'ah is the view of Muslims in general, that the concept of shari'ah seems to exist only in the last version of Islam brought by the Prophet Muhammad. Whereas what actually happened, all the teachings of obedience to Allah (Arabic phrase 'Din Allâh) naturally 
contain teachings about a form of shari'ah. Because the Shari'ah itself is etymologically, as explained in the book, Lisân al-'Arab, is a place for water to flow, it can also be a source of water through which humans pass, then humans will drink from it and take the water, or the human path to water sources ( mawrid al-mâa), namely the way to the main source of life; or a path to an oasis, and the Arabic for that oasis is jannah. The Arabs do not call this flow of water 'al-syarî'ah', unless the water is full and the flow is not interrupted, so that it becomes a separate phenomenon which cannot be pedaled with a bucket (Ibn Mandhûr, $1375 \mathrm{H}$ ). Hence the expression, the path to heaven, is borrowed as a metaphor, the path to happiness. In a more religious use, this word has the meaning of "a good way of life" namely religious values that are expressed functionally and in a concrete sense, which are shown to direct human life (Zaydân, 2002:24; Madkur, t.th. .:11; Rahman, 1984: 140). When associated with the term Islam, it means the route or path established by Islam to God by carrying out His teachings. The equivalent concept of syiari'at in Islam is the concepts of shirâth, sabîl, tharîqah and manhaj, because they all have the basic meaning, 'way, method, or method' ('Ali \& Muakdum, 1996:1174). In other religions, according to Nurcholish Madjid, these concepts are expressed in distinctive terms, such as "Dharma," "Marga", and "Tao". The Prophet 'Isa al-Masih called himself the 'way', because by following the teachings of God revealed to him, humans will be on the right path towards God (Madjid, 2002: 53).

In addition to shari'ah, the word shir'ah is also used in the Qur'an with the verb 'sya-ra-'a', which means to establish shari'ah. The Qur'an states: He (Allah) established the Shari'ah for you, in the form of religion (aldin, the teaching of obedience), as He willed to Noah, and which We (Allah) revealed to you (Muhammad), and which We (Allah) willed to Abraham, Moses and Jesus. To uphold the religion, and do not divide in it. It is hard for the polytheists what you call to them. Allah draws (closer) to that religion whomever He wills, and guides to that religion whoever wants to return (to Allah) ", (Surah Al-Syrâ/42:13)

If we look closely at the word, it is clear that the Shari'ah is the same in all religions, namely in fundamental meanings. All believers are commanded to unite in this fundamental sense, and not to be divided. The meaning of 'shari'ah' has the same meaning as religion, which is also stated by al-Fayoumî. According to him, "al-shari'ah" is "al-Din", which means the place where humans draw water. So named, because it is clear and bright. The plural form, 'syarâ'i', and syar'a Allahu lana kadza-yasra'uhu means to explain or explain (Al-Fayoumî, 1342 H: 331-332). In al-Muhîth's dictionary, 'al-shari'ah' is what Allah has ordained for his servants, and something straight is evident from various ways, such as the lafazh 'al-syir'ah' is exactly the same as al-'itbah and students of al-syarîbah such as al-mushri'ah (Abadi, t.th.:44) in the chapter 'fashl al-syin'. Basically the religions are one, and all 
the Prophets and Apostles of God teach the same teachings, namely the teachings of obedience and submission to Allah whose obedience must be done with resignation, sincerity and a sense of peace (Katsir, 1987:164). If an obedience to Allah is carried out by force, without sincerity in the heart based on faith, then the teaching of obedience or din by itself is not valid in the sight of Allah and the person concerned will lose. Therefore, in the Qur'an there is a narrative about the nomadic Arabs who came to the Prophet SAW and reported their "faith" with a proud attitude, so Allah ordered the Prophet to respond by affirming that they were new to 'Islam' in the sense of simply submitting to Islam. obedient outwardly, while faith has not yet entered their hearts.

So the attitude of obedience to other than Allah (shirk) with an attitude of peaceful surrender (islâm) is not a true obedience, because this kind of attitude has tarnished consistent obedience to Allah (tawhîd Allâh). In the Qur'an it is emphasized that the attitude of peaceful surrender or Islam to Allah is the teaching of all scriptures, but many adherents of the scriptures follow different attitudes (Al-Shâbûni, t.th.:191). Then the Word of God in the form of shari'ah words is: Then I made you (Muhammad) follow a path (shari'a) in resolving this matter, follow that path, and do not follow the wishes of people who do not understand. (Surat al-Jâtsiyah/ 45:18). These words were revealed to the Prophet Muhammad SAW, after a series of descriptions of God's power over all nature, and how humans relate to nature and to fellow humans, including the use of nature in accordance with the concept of caliphate (Al-Maraghi, t.th. : 152).

The word 'shari'ah' in the word of Allah above covers all aspects of obedience and submission without being divided to Allah, starting from aspects of aqidah, worship, muamalah, jinayah, natural management and morals. Muhammad Ali al-Thahanawi, an expert in Islamic law who is thorough in the study of terminology, as quoted by Jamal al-Banna explained, Shari'ah is something that has been determined by Allah to His servants regarding the law that was conveyed to the people through His prophets. , including the Prophet Muhammad SAW, whether related to the ways of doing charity, branching (furu'iyyah), which is structured in the form of figh disciplines, or those relating to matters of faith that are principal (ushîliyyah), which are arranged in the discipline of kalam. , as well as with regard to morality, which is the study of moral science Al-Banna, 1995:26). The definition of shari'ah above was clarified again by 'Abd al-Fattâh Kabbârah, with the following words:

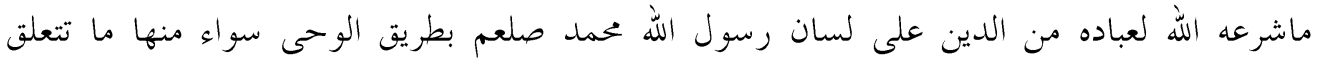

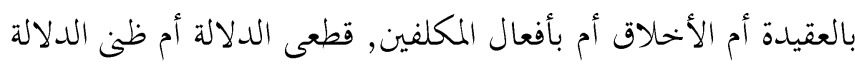

Thus, shari'ah in a broad sense is the same as religion (al-din), namely all God's rules to be practiced by His servants, in order to achieve salvation 
in this world and the hereafter. Shari'ah in this sense is commensurate with the shari'ah that was revealed to Prophet Moses, Prophet 'Isa and other prophets. 'Abd Allâh Ahmad al-Na'îm further emphasized that shari'ah is a very comprehensive Islamic normative system, covering issues of law, creed, doctrine, worship rituals, and the interaction of social relations or the totality of human obedience to God (The Totality of God), obligation to God) (AlNa'im, 1994:25). The concrete content of Shari'ah can only be understood through human interpretation, so Shari'ah itself is a combination of divine and human nature because there is no way to understand, except through the process of human reason. Therefore, one of the basic characteristics of religion is dynamic, following the times and social changes. Therefore, in the teachings of Islam there is ijtihad, the spirit of which is to try and keep trying until a truth is obtained according to the level of human ability. According to the Prophet, if true ijtihad gets two rewards, if it's wrong it still gets one reward (al-Zuhayli, 1987: 1038).

Based on the discussion of shari'ah above, it can be concluded that shari'ah contains three meanings: (1) law related to faith, in the form of monotheism, the last day and others, which are then included in the discussion of 'kalam science'; (2) Laws relating to education and the perfection of the soul, through which life becomes perfect and beautiful, so that it is far from ugliness and misery. Problems related to the values of human actions that can be characterized by good and bad will be studied in the 'science of morality'; (3) Laws related to individual deeds, such as ritual worship, social interaction (mu'amalah), various criminal penalties and constitutional law, which are specifically discussed in 'science of $f i q h$ '.

The term shari'ah is so broad, it turns out to be narrowed in Islamic studies that are more specific among recent scholars, thus distinguishing between aqidah and shari'ah or between faith and charity, as was done by Mahmûd Shaltut, the Grand Imam of al-Azhar who stated : Allah has given to the Prophet Muhammad, the foundation that has been united in Islam, namely aqidah and shari'ah, which is contained in the Qur'an. The Qur'an for Muslims is a source for knowing the basic teachings of Islam. From the Qur'an it is known that Islam has two basic teachings, without referring to them, the substance of Islam will not be obtained, and its meaning will not be realized, unless we direct our minds, hearts, and lives to both, Akidah and Shari'ah. (Syaltut, 1980: 9).

According to Saltut, the combination of these two things can be found in the Qur'an. Islam is not just a belief, which only prioritizes the relationship between humans and their God. Akidah is the principal (ushûl) and shari'ah is the branch (furû'). Every practice must be based on solid faith, which can lead to motivation to give birth to sharia and good deeds (Syaltut, 1980: 9). 
Shaltut's view above is in line with Sayyid Sabiq who stated that Islam is the religion of Allah revealed to the Prophet Muhammad SAW. Islam is faith and charity. Faith is the creed that is the basis for Islamic law. Faith and charity or aqidah and shari'ah are interrelated and related, like the fruit of the tree, or cause and effect, or like the conclusion of the premises. Therefore, the Qur'an always associates good deeds with faith. When the Qur'an mentions religion (al-din) as prescribed, then it means the religion that Allah revealed to His prophets. Religion in this shari'ah sense is only one, there is no difference between a prophet from another, between the first Prophet and the last Prophet. There has never been a change in the prescribed religion, even though there are differences in place and time (Sabiq, 1983: 7).

The religion of Allah is essentially one, whether it was given to Prophet Noah, Ibrahim, Moses, Jesus or Prophet Muhammad SAW. The unity of the essence of religion is found in the creed of monotheism. The teaching of monotheism is an eternal teaching that is called by all prophets, messengers of God to their people. In the Word of God above, "God has prescribed religion for you....... (Surah Al-Syra/42:23) refers to the meaning of ushûl from the teachings of religions, so that there is no element of changed or deleted (naskh) and there is no difference. However, elsewhere in the Qur'an mentions, the term 'shari'ah' has a special meaning, Allah says: For each of you, We give the laws of syir'ah, and a clear path, "(QS. Ma'idah/5:48). In this verse it is emphasized that every ummah has rules and laws given by Allah, which differ from one another. These rules have changed according to the development of the times and social changes (alZuhayli, 1991:217; Hamka, 1984:268).

Religion in the sense of shari'a specifically (furû) can undergo changes and will differ from one religion to another, even within one religion, there can be a process of changing the law, according to the situation and conditions. Moreover, if the law is based on ijtihadi, then the truth really depends on the interests of the people. In the context of changing the Shari'ah from one religion to another, the scholars of figh formulate a rule, "what Allah has prescribed to the people before us, also becomes Shari'ah for us, as long as there is no change from our Shari'ah." (al-Zuhayli, 1991:814). Shari'at of the prophets of the past, is a compilation of shari'ahshari'ah that has been established for all humans before the advent of Islamic law.

However, according to some 'Asy'ariyyah scholars, Mu'tazilites and some Shafi'iyyah scholars, the view that the shari'ah of the past prophets was used as shari'ah was only related to religious matters (al-din), while the shari'a 'at relating to the branch (furû'iyyah) which is the object of the study of jurisprudence does not become shari'ah for the people of Muhammad SAW. Some of their arguments are: First, the Word of God affirmation of God in His word, "For each of you, We determine the law (shari'ah) and a 
clear path," (Surat al-Ma'idah/5:48). This verse shows that the provisions of sharia law only apply specifically to each people. Second, the hadith of the Prophet Muhammad SAW, who sent Mu'ad ibn Jabal to Yemen clearly explains that the taking of the law, after it is not specified in the Qur'an and Sunnah, goes directly to ijtihad which is one's own opinion, and is not mentioned in the Shari'ah. before us. third, even if there are differences of opinion among the friends, then for the solution there is no thought to refer to the Shari' ah before them (al-Zuhayli, 1991: 838).

Thus, something that is permanent and eternal that is not touched by changes with shifts in situations and conditions of place and time is the basic teaching related to faith, which is also called 'eternal shari'ah', while branch shari'ah (furu'iyyah) which As the basis of amaliah law which aims to regulate human life in the world and the hereafter, it must have a just character, grace and contain the wisdom of goodness. Therefore, every problem that leads to justice to injustice and injustice, from mercy to calamity and misery, from peace to destruction, and from wisdom to futility is not from the Shari'ah. Shari'ah has the character of justice, full of grace, and contains safety, goodness, benefit and wisdom from al-Khaliq to servants and His creatures (Sadzali, 1988: 117).

\section{The Elasticity and Relativity of the Shari'ah}

The term 'shari' ah', as stated above, which originally covered all kinds of aspects of life in the form of creed, law and morals, was then reduced, and then only related to human behavior, but still comes from God. Therefore, the subject of shari' ah is syar' $i$ ' which means Allah, and in certain cases it can mean the Prophet, as a metaphorical sense (majâzi) (Al-Munawar, 2004:12). The reduction of the notion of shari'ah lies not only in the notion that is only related to human behavior, but in the development of meaning, it is also considered identical to "figh or Islamic law" which is the result of the ijtihad of a mujtahid.

With this limitation, it can be concluded that shari'ah is God's revelation itself in its form in the form of texts of the Qur'an and the traditions of the Prophet which are completely valid and unquestionable. The understanding of the nashsh has entered the realm of interpretation which is no longer identical with the essence of the nashsh itself; meaning that if the text has a guarantee for its truth, then the understanding or interpretation of the text has become relative. If the maker of shari'ah or shari'ah is Allah, then the interpreter or the person who tries to understand it (fqîh), and more precisely the mujtahid is human. Thus, it is clear the difference between shari', i.e. Allah, or Khaliq with faqîh and mujtahid as creatures. 
With the description above, shari'ah means the source of figh itself and figh is the process of understanding shari'ah and at the same time as a product of fuqaha or mujtahid in determining the law that has a sacred source in the form of shari'ah or revelation. However, subsequent developments are often clearly seen, that there is a deeper reduction, namely shari'ah is used for things that are actually in the form of figh. There has been a misunderstanding here and it seems as if there is no problem, that Islamic law, figh and shari'ah are seen as the same, even though they are clearly very different, but because it has become a general term and its use is widespread, finally shari'ah is identified with " figh and Islamic law" (alAsmawi, 2005:27).

More popularly, figh (figh) is usually defined as, "the science of shari'a laws' (Islamic law), which deals with actions/actions derived from specific arguments (al-'ilm bi al-ahkâm al- syar'iyyah al-'amaliyyah al-muktasab min fairtraina al-tafsiliyyah)". A shorter definition was given by Abû Ishâq alSyayrâzi, namely 'knowing (finding) sharia law' by means of ijtihad (ma'rifah al-ahkâm al-syar'iyyah al-latî thrîquhâ al-ijtihâd) (al-Syayrâzi, 1900 :4). After becoming a separate discipline, the term figh (figh), or often also called Islamic figh, usually means "Islamic law". The "law' which includes al-ahkâm al-khamsah, the five Islamic laws, in figh is closer to the concept of "religious ethics", whose main characteristic is the realization of the value of worship which is full of reward (tsawâb) and torture (' iqâb) and have consequences in the hereafter. Judging from this scope, which is loaded with religious ethics, figh can generally be interpreted as 'the science of human behavior whose main basis is texts/revelations'.

With the reality of the meaning of figh, mujtahids and even Islamic jurists (fuqahâ) continue to develop their thoughts on Islamic law freely and show an independent nature without being bound by state authorities, there is even a slight friction between Islamic jurists (fuqahâamujtahidîn). with the government at that time, as happened to Abû Haniîfah, al-Syafi'i and Ahmad ibn Hanbal (al-Sayis, t.th.: 91). From such history, it is natural that it is later stated that Islamic law is essentially a product of scholars, even though it still bases its main sources on the Qur'an and the traditions of the Prophet. And when understanding the texts, a set of methodologies are needed, such as qiyâs, istihsan, mashlahah, and so on. However, what remains visible are the characteristics of the independence and individuality of these Islamic legal thinkers. Millions of books on Islamic law have circulated and developed as individual legal products, although later there were books on Islamic law which were officially written by the government as a codification of Islamic law which was declared officially valid in certain countries, such as al-Fatâwâ al-Amgiriyah in India, Majllat al-Ahkâm alAdliyah in Turkey, up to the Marriage Law and the compilation of Islamic Law in Indonesia. 
Islamic law in terms of the arguments or sources that point to it is broadly divided into two parts. First, Islamic law regarding something that has been clearly affirmed by qath'i arguments, in the form of Qur'anic texts and hadiths that do not contain interpretation or interpretation; second, Islamic law regarding something indicated by Zhanni's argument (alMusawi, 1966:216). This last Islamic law can change due to different situations and conditions, which causes differences of opinion among fuqahâ and mujtahid, so that figh is flexible, elastic, and relative. Therefore, the rule of law as a product of the ulama must be reviewed critically, considering the changes in time, space, and circumstances (li taghyyîr al-azminah wa alamkinah wa al-ahwâl), then reconstructed so that justice and benefit can be achieved. enforced.

The nature and character of the relativity of Islamic law can be seen from the differences in thought, understanding, and perspective, both related to the transmission and designation of texts, so that Islamic jurists (fuqâha'/mujtahidn) conduct reasoning, pen-tarjihan, intense study and benefit analysis, goodness and social changes, such as their differences regarding the size of the arrangement that is forbidden to carry out the marriage bond, the qisas law for forced murder and marriage without the guardian's permission. Likewise, when they differ (mukhtalf 'alayh) when interpreting the word "lamastum" (Surah Al-M^a'ida: 43) which can be interpreted as "touching" and "having intercourse" (Madani, 1404:1999). At this point, when determining textual instructions or establishing laws for events/cases (hukm waqi'i) that occur, they are not absolute or relative, because each of the views of these scholars has strong arguments and arguments, so that not a few of them agree. considers, views and acknowledges the validity and truth of his opinion.

Meanwhile, the elastic character of Islamic law can be monitored in the determination of law based on space, time and circumstances. Because in determining legal issues, the Qur'an always pays attention to the social conditions that develop in society. Thus, it is very logical if the Qur'an deals with a problem, only stated in a global context, then developed according to the needs of each. Therefore, the understanding of the texts must be in line with the principles and methods of establishing laws that exist in the community. There are at least five kinds of principles for determining the law. First, giving leeway and not constricting ('adam al-haraj), in accordance with human capabilities as the object of implementing the law. For example, someone who is on a long journey or is sick, the fasting obligation may be postponed, and replace it after returning from a trip or after recovering from illness.

Second, reduce and prevent humans from difficulties, so that the burden becomes light (taqlîl al-taklîf). The Prophet Muhammad SAW in 
interpreting the verses of the Qur'an adapted to the needs of the people at that time, so that those that were not needed were left alone, so that the verses concerning the matter could be interpreted according to the conditions of the time and the environment. Third, the gradual determination of the law (al-tadrîj fi al-tasyrî'), so that the process of prohibiting a problem that has become a strong tradition can be accepted by the community consciously and sincerely, such as in the process of prohibiting alcohol, determining family law, economics, jinayat and things that lead to the development of the benefit of individuals and society (Syalabi, t.th.:26). Fourth, in line with human benefit (mashlahat al-nâs), so that some scholars say, wherever there is benefit, there is Islamic law (Ash Shidieqy, 1989:33). Islamic law wants human needs to be met, because the goal is also for happiness in this world and the hereafter. Fifth, equality and justice (al-musawat wa al-'is) before the law for all humans regardless of skin color, ethnicity, race and religion, so that the maintenance of human dignity (basyariyyah insaniyyah) will be realized.

With the description above, it can be stated that the legal texts of the Qur'an which only place general principles, contain flexibility, elasticity and dynamics, which can be detailed as follows: First, the legal texts in the Qur'an not only outline in one way for each branch of legislation. This can be seen from two categories, namely categories related to the laws of worship and those concerning domesticity, the texts of which are generally detailed in such a way that they are easy to study; while the other categories relate to practical issues that are not related to these problems, such as jinayat, civil and economic matters, including their implementation, which can vary according to the needs, circumstances and guidance of the local community (Qardhawi, 1987:73). Second, the meaning contained in the Qur'anic texts can not only be understood textually, but also contextually. According to ushul figh scholars, a text can at least have a double meaning, when viewed from its dalâlah, namely dalâlah manthûq and dalâlah mafhûm. Dalâlah manthûq is a meaning that is taken from the textual (denotative) textual text, while dalâlah mafhm is a meaning that can be understood in context (connotative).

Third, the texts of the Qur'an not only stipulate a law that is limited to 'illat or the main benefit as the basis for determining the law, but the 'illat or the main benefit contained in a text, can be used as a basis for analogy in determining the law of a new problem that is in line with the law. with 'illat and the main benefit. And fourth, the Qur'anic texts on practical legal aspects such as civil law, jinayah, state administration, economics are perfect in laying out general principles and basic rules. Therefore, the scholars of figh have compiled various rules of figh or istinbath based on an understanding of the general principles contained in the texts of the Qur'an, such as the rule, 'al-ashl fi al-asyyâ al-ibâhah. Thus, the various rules explored by the scholars, in order to realize the values of the Qur'an as a 
universal guide in all aspects of life, so that at this point of understanding lies the elasticity and flexibility of law enforcement.

\section{Islamic Shari'a and Human Rights}

Human Rights (HAM) according to Jan Materson from the UN Human Rights Commission are rights inherent in humans, without which it is impossible for humans to live as responsible human beings (Human Rights could be generally defined as those rights which are inherent in human rights). our nature and without which we can not live as human being). The meaning of human rights is very broad, because it includes all-natural rights that are given directly by God the Creator, therefore there is no power whatsoever that can revoke them.

The idea or concept of human rights has developed long before the Universal Declaration of Human Rights on December 10, 1948. Historically, the idea of human rights has emerged in the early thirteenth century AD as contained in the document Magna Charta in 1215 AD, later also found in the Petition of Rights in 1628 AD, and Bill Rights in 1689 AD. The development of human rights thought, among others, was heavily influenced by the thoughts of philosophers such as Thomas Hobbes, John Locke, Jean Jacques Rousseau. etc. The idea of human rights continues to roll as manifested in the spirit of anti-slavery, anti-violence, labor protection and so on. The killings and devastating violence in World War II have aroused the determination of the international community to take preventive measures to prevent war by building an international organization that is able to defuse humanitarian crises and provide a forum for discussion, discussion and mediation.

This idea was later transformed into an organization of the United Nations which would later play an important role in the protection of human rights. Through the Human Rights Commission, the United Nations succeeded in formulating the Universal Declaration of Human Rights which was approved by the United Nations General Assembly in 1948. The Declaration document globally contains: the right to life free from torture and cruel punishment, the right to protection from discrimination on the basis of sex, color skin, race, religion and language, the right to equality before the law, the right to freedom of thought and expression, the right to obtain legal recognition anywhere, the right to freedom of religion, association and assembly, the right to work, the right to education and teaching and the right to marry and have a family. This document also emphasizes the protection of equality for women and welfare, and explicitly provides the right to protection from acts of racial discrimination. And the most monumental thing is that human rights are undergoing a rapid internationalization process to all corners of the world, including Muslimmajority countries which are seen as less harmonious in the implementation 
of the UN Declaration of Human Rights. As a consequence, the Declaration of Human Rights is not only binding on nations, but is also seen as a basis for international action and concern. Human rights are rights that already exist by themselves, so they do not depend on recognition and application in a customary or legal system in a particular country.

The concept of the UN Human Rights declaration then underwent further elaboration, with the ratification of three international agreements or agreements, namely the International Covenant on Civil and Political Rights, the Covenant on Economic, Social and Cultural Rights. Rights), and the Optional Protocol, which was adopted by the UN General Assembly in 1966 $\mathrm{AD}$. These legal instruments, together with the general declaration and the second choice protocol adopted in 1989, constitute an international treaty on human rights (International Human Rights). Bill of Human Rights) which is widely known today.

The concept of human rights as mentioned above and the various treaties that follow show that human society is seen in the eyes of secularism, and religion cannot be defined as an order that binds society, the state or international relations. Laws were seen as secular, independent of any particular religious authority. According to the Declaration of Human Rights, the competence possessed by all religions in the world really lies only in the free choice of a person and the choice of parents regarding the education of their children. But religion has no competence whatsoever with the law, because the law must be enforced fairly regardless of the religion adopted. The basis of government authority is the will and choice of the people, human sovereignty, democracy and not something divine.

Due to its secular orientation, the concept of modern human rights above has given rise to varied and controversial responses in the Islamic world. Whether the concept of human rights is accepted or not depends on how Muslims view the complex issues surrounding sharia or the Islamic legal order. There are at least three responses from the Muslim world to the UN concept of human rights. First, reject it in its entirety, because Islamic Shari'a is sacred, independent and at the same time can overcome any conditions. In addition, shari'ah is the most correct and perfect system of life, while the UN concept of human rights is identical with Christianity, which is often tainted by practices that pollute human rights. Second, accept the concept of human rights as a whole. Because the Declaration of Human Rights and other treaties are human treasures, so there is no need for Islamic justification, even Asghar Ali Engineer, an Indian Muslim thinker, argues, the declaration of Human Rights can be used as a fairly good framework to state what he views as human rights according to Islam. And Third, partial acceptance and partial rejection of the UN Declaration of Human Rights. This group believes that sharia is eternal, universal and must be used as the 
basis of life, but that does not mean rejecting the Universal Declaration of Human Rights of the United Nations.

The UN Declaration of Human Rights can be accommodated with several prerequisites. This is due to the different philosophies between secular Western countries and Muslim countries that do not let go of the shari'ah aspect. So to show that Islam really respects human rights, a formulation of the concept of human rights is drawn up that is in line with the Shari'ah. The most famous formulation of Islamic human rights is the Universal Declaration of Human Rights in Islam (al-Bayân al-A'alâm 'an Huqûq al-Insân fi al-Islâm). The declaration which was promulgated in 1981 $\mathrm{AD}$ in Paris has very different characteristics from the UN Declaration of Human Rights. First, his claim that Islam has a guine concept of human rights that has been formulated since the seventh century AD. Second, the whole Declaration was formulated based on the Qur'an and Sunnah; third, what humans actually have are not the rights they are born with, but the prescriptions that are commanded to humans as divine decrees that include rights and obligations; fourth, Islamic law is the last and only parameter to judge human actions.

Then came the Islamic version of the Declaration of Human Rights sponsored by countries that are members of the Organization of the Islamic Conference on August 5, 1990 in Cairo. The concept of human rights of the Organization of the Islamic Conference (OIC) countries which has been debated for nearly 13 years is called the Cairo Declaration (CD). The Cairo Declaration of Human Rights has 25 articles that have some similarities to the Universal Declaration of Human Rights (UDHR), which include: The right to equality and freedom (article 19 CD and 7 UDHR), the right to life, freedom, independence and security personal rights (articles $2 \mathrm{CD}$ and 3 UDHR), the right to obtain protection, even in a state of war (articles $3 \mathrm{CD}$ and 5 UDHR); the right to honor and personal security (article 4 CD and 12 UDHR), the right to marry and have a family with anyone (article $5 \mathrm{CD}$ and 16 UDHR), women's rights are equal to men without discrimination (article $6 \mathrm{CD}$ and $2 \mathrm{UDHR}$ ), the rights of children from parents to form themselves into strong and responsible human beings in dealing with life (article $7 \mathrm{CD}$ and $25 \mathrm{UDHR}$ ), the right to obtain education and participate in the development of science (article $9 \mathrm{CD}$ and 26-27 UDHR), the right to freedom to choose religion and belief he wants (articles $10 \mathrm{CD}$ and $18 \mathrm{UDHR}$ ), the right to freedom of action and seek asylum to guarantee life (articles $12 \mathrm{CD}$ and 13-14 UDHR), the right to work in order to meet the needs and survival in the world (article $13 \mathrm{CD}$ and $23 \mathrm{UDHR}$ ). ), the right to obtain equal opportunities in business and work (article 14 CD and 21 UDHR), personal property rights that must be respected by anyone (article $15 \mathrm{CD}$ and 17 UDHR), the right to enjoy the results or products of science according to 
their interests. and necessities of life (articles 16 CD and 27 UDHR), and the rights of detainees and prisoners (articles 20-21 CD and 9 UDHR).

Based on the comparison of the two concepts of human rights above, it can be seen that the apologetic color is so striking. If you look at the body, it doesn't look much different from the UN Declaration of Human Rights, only here and there are modifications, such as the statement, that all rights will be guaranteed only if the rights are protected by Islamic law. This statement bears a formal resemblance to the content of the UN Universal Declaration of Human Rights, but at the same time, incorporates a standard Islamic law that controls everything. In this Cairo Declaration of Human Rights, it is seen that in the socio-economic field, it contains many fundamental matters, such as the right to associate. This is possible, because there are still many Islamic countries that sponsor this declaration, adopting an authoritarian ideology, which does not give freedom to its citizens.

From the explanation of the two concepts of the Declaration of Human Rights above, it is then rolled into the discourse of Islamic Shari'a, or Islamic Jurisprudence. In the study of figh, the concept of rights has two directions, namely human rights (huqûq al-insân) and God's rights (huqûq Allah). God's rights underlie human rights, and vice versa, so that no one is separated from these two rights. This division of rights becomes the basis for the normative provisions that exist in the Islamic Shari'ah itself, so that matters concerning human rights, then their business is with humans themselves, only then with Allah. If someone commits a mistake such as corruption, which involves property belonging to another person or the people, then to obtain freedom of prosecution later in the hereafter, he must make a clarification with the people as a whole, after that Allah will forgive him, and vice versa if someone does not do the clarification by apologizing. or accountability to the owners, then Allah will not forgive him until the man himself who has the right makes a clear release of his rights.

These kinds of rights exist in figh discourses and figh proposals. The problem is, when these rights are defined as being based on God's rights, then they are distorted, so that the rights that should be protected by those who regulate the government are actually controlled, because the government places itself as the embodiment of God, and is even more possessive of the rights that exist in humans. . The rights seized are not only the rights of Adam, but also extend to the rights of God which should be upheld for human peace. One example is the law of riddah. In the beginning, riddah is a right for everyone, because the Qur'an confirms: "Whoever wants to believe, then believe and whoever wants to be a disbeliever, let him be a disbeliever, indeed We have prepared for the wrongdoers hell." (QS. . AlKahf/18: 29). The choices of faith or kufr are all individual choices, so that converts or converts to religion is a right related to Allah's right to believe or not believe in a particular religion. But then, God's rights are taken over by 
the government or private parties who function as God to force people to stick to their religion or impose sanctions for people who change religions (apostates). It is this pattern that makes human rights crucial and controversial in the Islamic community.

In the figh books and figh proposals studied among Islamic jurists (fuqaha), there are five certainties which are then interpreted in the discourse of human rights. into five principles. The five principles of human rights are: (1) The right to protect the soul or the right to life. The most elementary translation of the right to life is contained in the legal system, one of which is the qisas law, because life is something that is absolutely necessary and cannot be violated by anyone, so that someone who intentionally violates the life of another person must be punished accordingly, so that people it doesn't do the same anywhere else. (2) The right to protect beliefs. This protection is stated in the teachings, lâ ikrâha fi al-dn, and lakum dînukum wa lia din, (Surat al-Baqarah/2: 256 and al-Kâfirûn/109: 6). Therefore, there is no coercion in embracing religion. But in later history, this right to protection of religion was translated into legal rules that gave strict provisions for people who changed religions. (3) The right to protect the mind. This right to protection is translated into very elementary legal instruments, namely the prohibition of eating or drinking which can damage the consciousness of the mind. (4) The right to protect property rights. This protection is translated into laws regarding the prohibition of stealing and harsh penalties for theft of legally protected property. (5) The right to have a family or the right to obtain offspring and maintain a good name. The right to maintain a good name is interpreted in figh which is so harsh on people who commit adultery. A person who accuses someone of committing adultery must be able to prove the accusation with the evidence of 4 witnesses.

In addition to the five rights above, there are three layers of figh and figh proposals. First, basic rights (dharuriyât). If this basic right is violated, it will not only be miserable, but human dignity will be lost. Second, secondary rights (hajiyât), namely rights which if not fulfilled will result in the loss of elementary rights. And the three tertiary rights (tahsiniyât), namely rights whose level is lower than primary and secondary. Then, figh and figh proposals, which functioned as an elaboration of these rights and obligations, shifted and became more escapist towards the power struggles that existed at that time. This distortion continues until in the end, the discussion about human rights and God's rights narrows to the rights of God alone. This right is then understood and implemented by the authorities, so that the figh discourse slumps to a discourse that only focuses on 'ubûdiah figh or ritualistic figh. That is, everything that is determined by religion regarding rights is understood as the right of God and is approached by the concept of $t a^{\prime} a b u d i$, so it is not surprising that this kind of 
approach negates reasoning efforts. This ecapistic discourse then makes the human rights conceptualized in huqûq al-insân not appear, as if there is only human necessity to deal with Allah alone. This understanding is strengthened when Sufism emerges, where the tarekat movements prioritize certain wirids without any contemplation or appreciation.

After contact with the concept of the UN Declaration of Human Rights, more conceptual issues emerged regarding the rights understood within the Islamic Shari'ah environment, especially those concerning the five basic rights. Among these basic rights, the most crucial are those relating to non-Muslim citizens, because within the scope of shari'a or the concept of figh there is a significant difference between the rights of Muslim and nonMuslim citizens. In history, it is told, the Jews and Christians who were bound by the 'Medina Charter' agreement agreed that they must overcome attacks from outside together. Therefore, there was cooperation between them in dealing with the attacks of the Quraish group, but a few moments later inter-religious conflicts began to emerge, resulting in a thick war with religious colors. Since then the verses of the Qur'an and the hadith of the Prophet have an exclusive nuance, so it is not surprising that teachings such as "man baddala dinan fa uqtuluh" appear. Relations with other religious groups have also begun to be overshadowed by the stigma of inter-religious conflict, therefore Muslim and non-Muslim citizens are distinguished in certain rights. For example, in Indonesia a polemic has arisen, whether or not a non-Muslim can become a head of state, actually departs from that understanding. Whereas the Qur'an essentially gives the principle of 'freedom of religion and belief, and the Prophet Muhammad SAW in his life never forced Islam to Jews and Christians, but the discriminatory understanding of non-Muslims is a product of past laws, making it difficult to communicate. between Muslims and non-Muslims, even at this time with the emergence of various types of violence against non-Muslims, causing Muslims to be increasingly cornered in international relations.

In addition, there are other issues that are no less interesting in the discourse of Islamic law, namely in viewing the position of women. This issue is almost as complicated as the issue of religious differences. Even though Islam claims that it is a religion that radically positions women as the same subject as men, in its application of more detailed normative rules, what is called gender inequality, especially if you look at historical facts. where religious interpreters are almost entirely monopolized by men. Regarding the position of women being judges only, in classical figh there are three major views: first, women cannot be judges at all. This is the opinion of Imam al-Shafi'i, whose madhhab is embraced by most of the Indonesian people. Second, women can become judges, only for transaction cases and not for jinayat cases. This is the opinion of Imam Ab Hanifah. And third, women can be judges for all cases and cases. This is the opinion of Ibn Jarr al-Tabari. This third opinion in the world of figh is considered a foreign 
opinion (garîb), unpopular which is almost never followed by the people. In addition, women are not allowed to become leaders, let alone become heads of government. This kind of understanding cannot be separated from sociocultural realities, in addition to the absence of women's involvement in public affairs, so when socio-cultural conditions are more open, women's opportunities to gain knowledge and achievements are wider, then Islamic law or figh regarding the position of women needs to be redefined.

In this case, the focus should be on achievement and ability to carry out work as a mandate, so that there is no discrimination whether male or female in carrying out the mandate. The most important thing is who is able to carry out the mandate with the best performance. If a choice is made, who has more right to occupy certain public positions, men who can't afford it or women who can afford it? The answer is that it can, even if it's a woman. On this side, there has been a reform of Islamic law, because it eliminates gender discrimination, as a demand for change, as stated in the UN Declaration of Human Rights and the Cairo Declaration of Human Rights.

In connection with the two issues above, it is interesting to observe the views of Ahmed An-Na'im in his famous work, 'Deconstruction of Shari'ah'. According to him, the alternative basis for reforming Islamic law was revelation to the Prophet Muhammad in the first phase of his mission in Mecca. Why are many Meccan verses deleted and not the basis for consideration of legal ijtihad. The message of Mecca is an eternal and fundamental Islamic message, which emphasizes the inherent dignity of all human beings, regardless of gender, religious beliefs, race and others. This message is marked by equality of men and women and complete freedom to choose in religion and faith. Whereas the Medina verses are a practical and realistic compromise, when the highest level of the Meccan message is unacceptable to the historical community. Therefore, if the verses that were revealed in the Meccan period can be called universal-egalitarian-democratic verses, then the verses that came down in Medina (Madaniyâh) can be called sectarian-discriminatory verses.

Here, An-Na'im presents a radical starting point from both modernist and fundamentalist Islamic positions, both of which dominate contemporary thought in the Islamic world. An-Na'im tried to transform the understanding of the basics of traditional Islamic law. In terms of shari'ah, An-Na'im advocated a new comprehensive system of Islamic law which was believed to provide a more suitable basis for Islamic life in the contemporary world. This is a comprehensive formulation in dealing with the political structure, social order, criminal law, international law and human rights. Therefore, the intellectual foundations for a radical and comprehensive interpretation of the nature and meaning of Islamic law must continue to be developed, especially the balance of the rights of Muslims and non-Muslims 
as well as men and women in self-determination. With the redefinition, reactualization and reform of Islamic law, the actual legal issues that arise at this time can be placed in a proportional and elegant position.

\section{CONCLUSION}

Based on the explanation above, it can be concluded at the end of this paper as follows: (1) Political liberalization in Indonesia will bring up the abundance of aspirations and expressions of Muslims in an effort to formalize Islamic law. (2) The term Shari'ah which was initially broad, covering all aspects of life and devotion, became distorted, until its meaning was narrowed and narrowed to figh or Islamic law. (3) Shari'ah as a human product is elastic in character, can change at any time, is relative, not final and is relative in nature according to the conditions of place and time, so that one day it can be reconstructed again. (4) The United Nations Universal Declaration of Human Rights, which is similar to the Cairo Declaration of Human Rights, has essentially been discussed in figh studies and figh proposals, only that certain issues are still crucial and controversial, such as religious conversion and equality between men and women. (5) The treasures of classical thought which were considered foreign and unpopular at the time, needed to be reconstructed and matched with contemporary thought. In dealing with global problems, Islamic Shari'ah must be carried out: redefinition, actualization, reinterpretation, reconstruction and reformulation, so that it is in line with the developments of the times faced.

\section{REFERENCES}

'Ali, Atabik dan Zuhdi Muhdhar (1996) Kamus Krapyak al-'Ushri, ArabiIndonesi. Yogyakarta: Muassasah 'Ali Maksum

Al Munawar, Said Agil Husin (2004) Membangun Metodologi Ushul Figh: Telaah Konsep Al-Nadb dan Al-Karahah Dalam Istimbath Hukum Islam. Jakarta: Ciputat Press

al-Asmawi, Muhammad Said (2005) Problematika Dan Penerapan Syari'at Islam Dalam Undang-Undang, trj. Saiful Ibad.Jakarta: Gaung Persada Press al-Banna, Jamal (1995) Naḩwa figh al-Jadî̀. Kairo: Dâr al-Fikr al-Islâmi. al-Fayoumî, Ahmad ibn Muhammad ibn 'Ali al-Muqrî (1342) al-Mishbâh alMunîr fi Gharîb al-Syarh al-Kabîr li al-Rafi'i. Mesir: Mathba' ah al-Halabi al-Khallâf, 'Abd al-Wahhâb (1978) 'Ilm Ushûl al-Fiqh.Kuwait: Dâr al-Qalam al-Marâghi, Ahmad Musthâfâ (t.th.) Tafsîr al-Marâghî. Beirut: Dâr al-Fikr li Thibâ'ah wa al-Nasyr al-Shâbûni, 'Ali (t.th) Shafwâh al-Tafâsir. Beirut: Dâr al-Fikr al-Syayrâzi, Abû Ishâq (199) al-Luma' fî Ushûl al-Fiqh. Kairo: Muhammad 'Ali Shabih 
al-Zuhayli, Wahbah (1987) Ushûl al-Figh al-Islâmi. Beirut: Dar al-Fikr alMu'âshir

An-Na'îm, Abdullah Ahmed (1990) Dekonstruksi Syari'at, Wacana Kebebasan Sipil, Hak Asasi Manusia dan Hubungan Internasional Dalam Islam, trj. Ahmad Suaedy dan Amirudin ar-Rany. Jogyakarta: LkiS

Azizy, A. Qodri (2004) Hukum Nasional: Eklektisisme Hukum Islam dan Hukum Umum.Jakarta: Teraju

Fadhlallah, Mahdi (1987) al-Ijtihâd wa al-Manthiq al-Figh fî al-Islâm. Beirut: Dâr al-Thâli'ah

Hamka (1984) Tafsîr al-Azhar. Jakarta: PT Pustaka Panjimas

Kabbârah, 'Abd al-Fattâh (1997) al-Figh al-Muqâran. Beirut: Dâr al-Naâ'is

Katsir, Ibnu (1987) Tafsîr al-Qur'ân al-'Adhîm. Beirut: Dâr al-Kutub al'Ilmiyah

Lopa, Baharuddin (1996) al-Qur'an dan Hak-Hak Asasi Manusia. Jakarta: Dana Bhakti Prima Yasa

Madjid, Nurcholish (2002) Atas Nama Pengalaman, Beragama dan Berbangsa Di Masa Transisi: Kumpulan Dialog Jumat di Paramadina. Jakarta: Paramadina

Madkur, Salâm (t.th.) Târîkh al-Tasyrî' al-Islâmi. Kairo: Dâr al-Kutub

Mandhûr, Ibnu (1375) Lisân al-'Arab. Beirut: Shâdir

Mujani, Syaiful (2003) "Syari'at Islam Dalam Perdebatan", dalam buku yang diedit oleh Burhanudin, Syariat Islam Pandangan Muslim Liberal. Jakarta: Sembrani Aksara Nusantara

Nadj, E. Shobirin dan Naning Mardiniah (2000), Diseminasi Hak Asasi Manusia: Perspektif dan Aksi. Jakarta: Cesda LP3ES

Rahman, Fazlur (1984) Islam, Terjemahan Ahsin Mohammad. Bandung: Pustaka

Sabiq, Sayyid (1983) al-'Aqî̀ah al-Islâmiyyah. Beirut: Dâr al-Fikr

Salim, Arskal dan Azyumardi Azra (2003). The State and Shari'a in the Respective of Indonesian Legal politics, yang dipresentasikan dalam, Workshop on Shari'a: Comparative Perspectives, oleh Jaringan Liberal Islam (JIL), tanggal 10 Januari 2003 di Ciloto Bogor.

Syaltut, Mahmûd (1980) al-Islâm, 'Aqidah wa Syarî'ah. Kairo: Dâr al-Suruq Syazali, Munawir (1990) Islam dan Tata Negara: Ajaran, Sejarah dan Pemikiran. Jakarta: Universitas Indonesia Press

Zahrah, Muhammad Abû (t.th.) Ushûl al-Fiqh. Kairo: Dâr al-Fikr al-'Arabi Zaydân, 'Abd al-Karîm (2002) al-Madkhal li Dirâsah al-Syarî'ah al-Islâmiyyah. Beirut: Muassasah al-Risâlah 
